\title{
An Imperial Apostle? St Paul, Protestant Conversion and South Asian Christianity
}

\author{
SHINJINI DAS
}

University of Cambridge

\begin{abstract}
'The account so carefully given by St Luke of the planting of the Churches in the Four Provinces ... was certainly meant to be something more than the romantic history of an exceptional man like Paul, ... it was intended to throw light on the path of those who should come after. ${ }^{i} \ldots$ the answer comes with irresistible force that most of St Paul's converts were born in an atmosphere certainly not better and in some respects, even worse that which we have to deal today in India or China. ${ }^{\text {ii }}$

'Admit then, that Paul was a necessary logical adjunct and consequent of Christ, as Moses was, indeed, his antecedent ...If you cannot separate Paul from Christ, surely you cannot separate Paul from us. Are we not servants of Paul and Apostles of Jesus? Yes. ${ }^{\text {,ii }}$
\end{abstract}

St Paul, the apostle who taught the Gospel of Christ to the first-century world, is seldom remembered either in the historiography of Indian Christianity or that of the British Empire in India. This is remarkable considering the regularity with which St Paul, his life and his letters were invoked by both Protestant missionaries and Indian Christian literature, including converts' narratives. As the quotations above illustrate, Paul remained equally relevant for the two distinct nineteenth-century personalities. For Roland Allen, the late nineteenthcentury Anglican missionary to China, the ancient saint's activities provided the most robust blueprint against which to evaluate the future policies for missionaries in India and China. For the Indian theologian and founder of the Hindu-reformist sect Brahmo Samaj, Keshab Chandra Sen, Paul held the key to his Hindu reformist agenda. For both, Paul's life and letters were not simply an 'interesting detail of ancient history' but all-important in its message to spiritualise peoples. At a period when the historical origins of Christianity and the Bible were being reviewed afresh, and often challenged in scholarly circles, St Paul also received critical attention with relation to questions of evangelical missions, imperialism and conversion. He was projected as an advocate of the Roman Empire by some circles while others also appropriated his ideas to bolster radical critiques of imperialism or the caste system in nineteenth-century India. The figure of Paul therefore excited the imagination of a 
range of individuals invested in imperial Christianity. These included people as diverse as the esteemed Victorian scholar-missionary Joseph Barber Lightfoot; one of the founding figures of the Anglican Church in India Bishop Daniel Wilson; Victorian orientalists like William Muir; leading Hindu theologian-ideologues as Keshab Chandra Sen and Swami Vivekananda; as well as Bengali converts, such as Rev Lal Behari Day. A study of St Paul in the colonial context deepens our understanding not only of ideologies of empire but also the processes of Christianity's translation in colonial societies. The focus on Paul also enables us to go beyond the conventional Christ-centric paradigm of scholarship on Christianity's encounter with Indian religions. ${ }^{\text {iv }}$

The debate opened up by Jean and John Comarroff about the complicity of nineteenthcentury European missions with cultural imperialism continues to remain significant. ${ }^{\mathrm{v}}$ More recent works by Hilary Carey and Alex Bremner have delved deep into particular strands of the material, intellectual and cultural investments of the Christian Churches of Britain in the idea or institutions of empire. ${ }^{\mathrm{vi}}$ Meanwhile, more locally focussed studies are engaged in unravelling the specific interactions between the visions of 'the empire of Christ and the empire of Britain'. ${ }^{\text {iii }}$ An especially interesting line of inquiry has been opened up by R.S Sugirtharajah and others who have sought to explore the intersections of imperial ideas with certain nineteenth-century readings of the Bible. ${ }^{\text {viii }}$ This paper traces the remarkable interest in the figure of St Paul in nineteenth-century India to throw further light on the relations between these two empires. In so doing, it contributes to the studies relating to the appropriation and cultural reimagining of Christian and classical antiquity in the nineteenth century, especially in a colonial context. For although the idea of 'empire' features centrally in such accounts of nineteenth-century receptions of antiquity, much less work has been done on how the Bible both confirmed and problematized received narratives. ${ }^{\text {ix }}$ By focusing on St Paul this paper examines how these distinct visions of empire: that of Rome, Britain and 
Christ, overlapped and came alive in nineteenth-century imaginations to frame British imperial ideology. ${ }^{\mathrm{x}}$ It pays attention also to the material-visual aspects of such ideology especially with relation to Protestant missions to India.

Although some historians of Christianity emphasise the complicity of all nineteenth-century British Christian churches in fostering the vision of a 'greater Britain'xi , others have investigated and debated specifically the ambivalent relationship between institutional Protestant missions and the British overseas expansion. ${ }^{\text {xii }}$ Indeed, scholars have highlighted a strong strand of British anti-catholicism, culminating in the formation of the Imperial Protestant Federation of 1898 , that marked the nineteenth-century British vision of empire. xiii $^{\text {. }}$ Given these insights, this article chooses to focus exclusively on the Protestant writings on Paul as the British-Indian catholic literature of the period do not suggest the same kind of dynamic reading of St Paul with its associated political valence as its Protestant counterpart.

In its focus on the processes of cultural reception of Biblical Paul, the paper draws upon the growing work on transnational circulation of texts and ideas that analyses the newer meanings associated with texts as they undergo 'cultural translation. ${ }^{\text {xiv }}$ Over the past years there has also been a move inspired by postcolonial studies to explore South Asian Christianity in context, to understand the contours of "vernacular Christianity'. ${ }^{\mathrm{xv}}$ Drawing upon these insights, and in contradistinction to a largely Eurocentric existing historiography on biblical reception and scholarship, this essay highlights how nineteenth century reimagining of the apostle in British India resulted from dialogical interactions between European and South Asian voices. It explores the many ways in which Paul was reconceptualised in India: as a symbol of religious salvation, an inspiration for anti-colonial sentiments and as a model to reform and modernise orthodox Hinduism. In so doing, the paper situates itself within the new literature on Christianity that is grappling with ideas of 
'transculturation' and 'hybridity', to trace the entrenchment of Christianity in the colonial world, as simultaneously 'indigenous, foreign and hybrid. ${ }^{\text {xvi }}$

It sheds light also on the processes of religious conversion. Most work on conversion to Christianity in South Asia has focussed especially on the uneducated, lower classes, and have interpreted mass conversion as act of resistance. ${ }^{x v i i}$ Focussing on the plurality and fluidity of identities produced by conversion, others underline the need to conceptualise personal faith and belief systems of individuals. ${ }^{\text {xviii }}$ This paper contributes to this literature by exploring the link between the myriad recounting of St Paul's life and the histories of conversion. It examines the writings especially of Protestant missionary scholars, Pauline commentators writing for an Indian audience, Indian religious reformers and Indian Christian converts to reveal some of the intellectual and theological impulses for a change of faith by the Indian intelligentsia. It as well, examines the tensions implied in being a nationalist inspired by Christianity in British India.

\section{I}

The theme of empire featured centrally in a range of nineteenth-century Protestant evangelical pamphlets and monographs dealing with the role of missions in India. Juxtaposing imperial Roman and the British political experience, these texts highlighted the indispensability of an imperial context for the flourishing and dissemination of Christianity. Published mostly by English presses, often authored by reputed English Biblical scholars and running into several editions, these publications seemed more inclined to address British readers. The texts frequently focussed on the life of St Paul in the first-century Roman Empire arguing that the lessons learnt from St Paul's life were a way of informing nineteenth-century efforts in 'christianising India'. 
In his 1907 pamphlet Empire of Christ, Bernard Lucas, a London Missionary Society (LMS) missionary to India, devoted a chapter titled 'Paul and the Imperial Ideal' detailing the entangled historical relationship between Christianity and imperialism. ${ }^{\text {xix }}$ Even while acknowledging that for Paul 'the Roman ideal of empire was imperfect and transitory, the Christian ideal was complete and permanent', Lucas emphasised how strongly committed Paul remained to the ideal of Roman Empire for his missionary purposes. ${ }^{\mathrm{xx}}$ For the apostle ${ }^{\mathrm{xxi}}$, the long-term salvation of the people, achievable in a future kingdom of God was possible solely through the prevalent political realities of imperial rule. Hence, 'as a Roman citizen he was deeply sensitive to the imperial ideal', while he dedicated his life to the future 'realisation of a Christian imperialism to which his genius gave birth.'xxii

What comes across remarkably from these Protestant missionary writings on India, is a profound sense of divine providence and historical continuity in shaping a Christian future through Empire. The history of Roman Empire was invoked recurrently. In 1884 George Adam Smith, the then secretary of the foreign mission committee of the Free Church of Scotland who had spent his early years in India wrote the suggestively titled $A$ Short History of Christian Missions from Abraham and Paul to Carey, Livingstone and Duff that captures the core spirit of these genre of texts. Smith elaborated on three historic epochs where imperialism and Christianity strengthened one another. In situating, contemporary England in a unique relationship with Greco-Roman antiquity, he argued, 'we are now approaching the close of the first century of the Third Missionary Epoch ... What Greece did in the first and Rome in the second, England or English speaking people are now called on to do on a far wider scale, co-extensive with the whole race. ${ }^{\text {xxiii }}$ The sense of a dialogic interaction with antiquity resonated heavily even with Biblical scholars such as Joseph Barber Lightfoot. In his Comparative progress of Ancient and Modern Missions, first published in 1874 and reprinted in his collection of Historical Essays compiled posthumously in 1896, Lightfoot 
elaborated on the ideas of entwined trajectories of empires and missions from antiquity to the nineteenth-century world, placing them squarely in the context of Christianising India. ${ }^{\text {xiv }}$ Comparing the success of the British and Roman missionaries, he proclaimed that 'by the middle of the third century native Gaul was not more Christian than native India is at the present time' ${ }^{\mathrm{xxv}}$ Paul and his exemplary success in evangelising were remembered in that context. Lightfoot held that the missionaries in India were facing similar hindrances to those that Paul faced whenever he approached an older civilisation like India, adding that Paul was more successful in Corinth with its 'mixed and floating population' than he was initially in Athens, 'the historic centre of Greek culture and religion., ${ }^{\text {xxvi }}$

The intense symbolic and theological significance of St Paul to Protestant evangelicals in the colonial world becomes most obvious once we focus more closely on individual figures of eminence. For the Anglican Bishop Daniel Wilson, Paul's letters to the early church held crucial key to the problems faced by the modern Protestant church in England. Although fifth in the order of succession, Bishop Daniel Wilson (1778-1858), nonetheless, was the most significant and the longest-serving Bishop for the see of Calcutta. After the bishopric of Calcutta was founded in 1814, the first of its kind in colonial India, and following the untimely death of the first four Bishops within nine years, Daniel Wilson was nominated to the see in 1832 by the evangelical politician and President of the Board of Trade Charles Grant with the concurrence of Prime Minister Earl Grey. Being a pioneering cathedral, the jurisdiction of the Bishop of Calcutta was powerful as well as unwieldy. The Bishopric extended over territories which eventually came to constitute sixteen large and important dioceses stretching as far as Ceylon and New Zealand. ${ }^{\text {xxvii }}$ Indeed, the Bishop had to exercise 'supervision as Metropolitan over the whole of India and Australasia.' ${ }^{x x v i i i}$ Given his stature and power in Calcutta, Wilson received almost immediately deputations of the British and Foreign Bible Society and the Church Missionary Society and accepted in both cases the 
office of the President. Rising to the challenge of introducing order and discipline in largely disorganised ecclesiastical matters in India, the Bishop, as part of his very first visitation speech in Calcutta in 1834, announced his commitment towards 'the settlement and future safety of our apostolical branch of Christ's Holy Church in India.' ${ }^{x x i x}$

The Bishop internalised the rationale of an 'apostolic ministry' ${ }^{\mathrm{xxx}}$ to an extent that in his lectures he regularly identified himself with Paul. Wilson's 1861 biography narrate that while still a Vicar at Islington, Wilson celebrated the news of his appointment as the Bishop of Calcutta by expounding St Paul's "Address to the Elders of the Church at Ephesus"' with his family that morning, holding that 'I also go to India under somewhat similar circumstances with the apostle. ${ }^{\text {xxxi }} \mathrm{He}$ drew upon Paul's epistle to Ephesians in many of his visitation charges as the Bishop in various parts of his huge Indian episcopate. Most evidently, his last and the seventh visitation charge delivered on October 23rd, 1855 was based on Paul's address at Ephesus which he 'carefully applied' to understand and explain 'the condition of the church and the character of the clergy in these later times'. ${ }^{x x i i}$

In his difficult endeavour of providing a solid foundation to the fledgling Bishopric of Calcutta, Daniel Wilson took refuge in St Paul's visions on innumerable occasions. Indeed, a substantial part of Bishop Wilson's publications involved the life and letters of apostle Paul. Apart from two lengthy sermons about the apostolic duties of the Bishop ${ }^{\text {xxxiii }}$, Bishop Wilson's collection of lectures and sermons in India drew upon Paul's epistles that comprised a bulk of the New Testament. ${ }^{\text {xxiv }}$ The most significant instance of Bishop Wilson's refuge to Pauline doctrine, was his Expository lectures on the Epistle to Colossians, which, as the subtitle of the book suggest, was 'an attempt to apply the apostle's argument respecting the errors on the subject of the mediation of Christ at Colosse to the present circumstances of the Church. ${ }^{\mathrm{xxxv}}$ First written in 1815 the lecture was revised and edited several times till the last lengthy edition was published in 1859. In 1842, Wilson rewrote the lectures for Lent lectures 
at the cathedral of Calcutta. ${ }^{\text {xxxi }}$ Over this period, particularly the editions published in the 1840s and 50s, the Epistle to Colossians was invoked by him to address several issues, most significantly, the twin problems of Tractarianism and the vexed question of evangelising India. The singular importance of the epistle in tackling these two-fold challenge for the English church was emphasised by Daniel Wilson as he wrote that 'of all the epistles of St Paul, there is, perhaps, no one more instructive, or more adapted to meet the errors of the times in which we live, than that addressed to the converts at Colosse. ${ }^{\text {xxxvii }}$ His ProtestantAnglican impulse was transparent as he emphasised that 'a general Christianity is not Christianity at all', and pointed out that along with 'proselytising our fellow Christians to our particular forms', the importance of 'converting the heathen and Mohamedan population'. ${ }^{\text {xxviii }}$ The address for Colossians was considered especially suitable for Indians as the Bishop drew parallels between the condition of Indian Hindus and Mahomedans with those of ancient Colossians before their conversion: 'alienated and estranged from real God and goodness, buried in superstition and vices'. ${ }^{\text {xxix }}$

In his Expository Lectures on the Epistle, Daniel Wilson recurrently emphasised the need to establish a truly English Protestant church in India, free from any polluting influence of Catholicism. Reminding the readers of the 'tender, instructive and cautionary' nature of the Epistle to Colossians, he detailed the background of this address, written by Paul from the Roman prison to address the customs and rituals introduced into the ancient church by the Jewish converts that threatened to deviate 'the flock from the simplicity of Christ. ${ }^{\text {xl }}$ Wilson's lectures drew regular comparisons between the crisis of the Church at Colosse to the OxfordMovement-inspired nineteenth-century crisis that dealt an 'extraordinary and contemporaneous assault upon the Protestant faith, and especially on our own church, which has for three centuries been the bulwark of it ... ${ }^{\text {xli }}$ The address to Colossians was necessary, 
according to him, for 'a right understanding of the Gospel and effectual exclusion of the most fundamental errors'. xlii

Wilson even went so far as to draw analogy between Tractarianism and heathenism. In lecturing on Colossians 1:12-13, the Bishop spoke of the satanic darkness that engulfed India - 'there Satan reigns, amidst the profound obscurity, with not a ray of light, except the remnants of tradition and the faint voice of conscience. ${ }^{\text {xliii }}$ He found reflections of the same kind of heathenism and idolatry among the Tractarians of the day as he discussed Epistle to Colossians II: 18-19, where he alleged the Tractarians of embracing the worst idolatries of Rome. ${ }^{\text {xliv }}$ Indeed, the Bishop posed Roman paganism, Hindu heathenism and the Tractarian trends as common enemies of the Protestant church, insisting on its safety from 'the dreams and delusions of Popish, Mahomedan and Brahminical fables' at once. ${ }^{\text {xlv }}$

Wilson argued that he emphasised the issue of building up an apostolic Protestant Church recurrently to get rid of the 'poison of Popery' and to ensure the conversion of India. For him, Tractarianism at home could be resisted by the establishment of English churches in the wider imperial outposts of Britain. Contending 'that our own church is founded on the apostolical model', Wilson made a strong argument for the Protestant purity of the Anglican English church. He pointed out that '... her Liturgy, her Office, her Articles and her Homilies were drawn up with greatest deliberations... it would well qualify her to give solidity and permanence to the young and feeble religion of India. ${ }^{\text {xlvi }}$ The building of Anglican Churches in India, he held, would further ensure the foundations of the British Empire in India.

\section{II}

Convinced with the idea that an Anglican church in the colony would be the panacea for all evils facing the British nation and Anglicanism at home and in empire, Daniel Wilson, in 
fact, devoted a significant part of his tenure as a colonial Bishop in building India's first cathedral. The construction of the cathedral begun in October 1839 and it was consecrated in 1847. From its moment of conception, Wilson was convinced that the cathedral should bear the name of St Paul. Wilson's own journal-entries in the early days of 1839 reveal his resoluteness in naming the cathedral after Paul. He saw it as a spiritual temple, whose chief corner-stone was inevitably Christ. The journal-entry for June $14^{\text {th }}$ distinctly pronounced, that 'I have called the Cathedral St Paul to denote the doctrine which I Trust will ever be proclaimed by its ministers and the examples of tenderness and fidelity which they will ever exhibit. ${ }^{\text {,lvii }}$ Weaving British national sentiments with chivalrous Protestantism, he further noted, 'I have chosen June $18^{\text {th }}$ for issuing my proposal ... because it is the anniversary of the victory of Waterloo, emblematic, I hope of the spiritual victory of Christ in my cathedral. ${ }^{\text {xlviii }}$ His plans with regards to the naming of his cherished cathedral were proclaimed emphatically in the long official report that he drafted of the cathedral's progress in 1841, where he pronounced, 'May the doctrine of St Paul be ever preached in this Cathedral, which is to bear his name. ${ }^{\text {xlix }}$ There are ample evidences to suggest that the future caretakers of the Cathedra carried forward Wilson's vision. Between 1870s and 90s the building was further extended and renovated, and the Eastern wall was constructed later, under the supervision of Archdeacon Luckman, who oversaw an elaborate mosaic portrayal of Paul's life beginning with his conversion from Judaism to Christianity and ending with his death. ${ }^{1}$ 


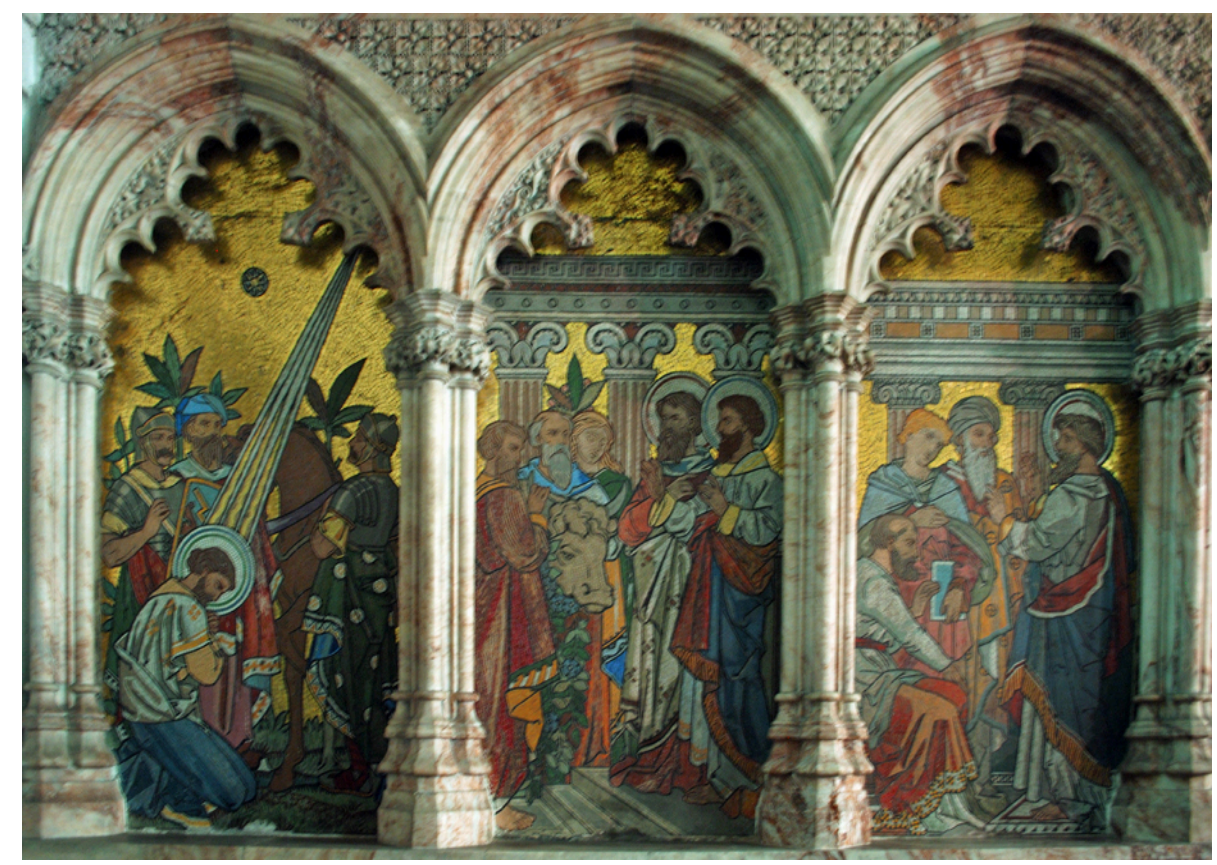

Fig. 1 Mosaic Life of St Paul, Altar, St Paul Cathedral, Calcutta. (From Personal Collection of Rangan Datta)

In his magisterial Birth of the Modern World, Christopher Bayly identifies the nineteenth century as perhaps the most important period of church building in Christian history since the high middle ages. ${ }^{\text {li }}$ Contributing to the growing literature on the relationship between Anglicanism and empire in the nineteenth century, Alex Bremner shows the political and ideological import of setting up churches in the colonies. ${ }^{\text {lii }}$ It is contended that by 1840 s it had become clear that religion was a central plank of Britain's wider imperial 'mission' and that the church buildings were the material manifestations of an influential set of principles that were transmitted around the globe. Indeed, the ecclesia cathedralis or the cathedral church was conceived as a core symbol of colonial Anglicanism. Daniel Wilson's scheme needs to be situated within this larger context.

Especially in the context of India, following the Victorian architect-historian James Fergusson's characterisation of Indian architecture as 'text in stone', there has been a literature exploring the colonial connections between architecture, race and civilisation. Thomas Metcalf pronounced the deeper dilemma animating the British through the colonial period of whether to impose the pure European style or to integrate creatively the Western 
and Indian style of architecture. ${ }^{\text {lii }}$ It is generally agreed that the British in India discarded eighteenth-century attempts at hybridisation by the 1830 s when a more confident architecture of British style took over. Yet the mutiny of 1857 provided a crucial blow to any attempt at imperial imposition and a distinctly hybrid form of architecture most commonly characterised as the Indo-saracenic style was developed over the latter part of the nineteenth century. St Paul's cathedral in Calcutta stands out because although it was built over the 1830s and 40s, it was self-consciously upheld by its founders as a hybrid structure of the unique 'Indogothic' style. The building marked the transition from the classical to a more gothic style of architecture, especially in British religious architecture in India, and it signalled the beginning of more pronounced evangelical energy in empire. ${ }^{\text {liv }}$

In his various Reports drawn on the building of the cathedral as also in other publications, Daniel Wilson voiced the urgent need for a 'grand' Protestant cathedral in India. His plans saw it as a moral and ideological scaffolding that would hold together the edifice of Britain's empire. He argued that as the creator of the 'finest empire in the world ... and for the consolation of their British subjects and their East Indian dependents' it was England's duty to build a proper cathedral. ${ }^{\text {v }}$ Moreover, Wilson was sure that it would be among the most enduring features of British presence in India.

Reminding the readers of the centrality of cathedral church and clergy to every English Bishopric since the time of the Reformation, Daniel Wilson underlined the fundamental necessity of the institution in a fledgling Christian community as India. ${ }^{\text {lvi }}$ The necessity of the cathedral to resist the two evils of Popery and Vedantism at once was highlighted. ${ }^{\text {lvii }}$ A threefold utility of the cathedral was drawn out in the Final Report on the Building submitted in 1847. ${ }^{\text {lvii }}$ While at one level it was to be a 'District or Parish church for the numerous Christian inhabitants around', the cathedral was also planned as a conduit for promoting native Christianity. It was designed as a "native or mission church for service in the 
vernacular languages'. More crucially, it was to be the Cathedral of the Metropolitan Diocese of Calcutta, acting as a 'Mother church of all the Sacred Buildings with their Ministers and flocks, whether European or Native in the Diocese. ${ }^{\text {lix }}$ Hence the necessity of a colonial Cathedral was felt not merely as an architectural ornament, but as a symbolic function of the glory of the English church and the maintenance of an apostolic tradition. He firmly believed that the newly built Protestant English Cathedral would 'give a local habitation and name to Christianity', which relates to India now, as 'it was to Asia Minor, Africa, and Europe in the primitive ages.'

Given Wilson's insistence on the reciprocal relationship between a protestant cathedral and the entrenchment of the colonial rule, it is unsurprising that he managed to convince the British government at home to share responsibilities of its building. The Final report of the cathedral clearly indicates that the major financial responsibilities were equally divided between the Court of Directors (Rs 1,50,000) and the Bishop of Calcutta (Rs 1, 45,000) with several other missionary societies and fund raising efforts in India and England covering the rest of the cost. The total expenditure amounted to around Rs 5, 00,000 (appox $£ 5000$ in today's terms). The 1841 Report, however, suggests that although the East India Company's Court of Directors, in consultation with the Governor General, promised a grant of a lac and a half of rupees, it carefully highlighted that it chose to 'distinctly stand aloof, as a government from its benevolent and missionary purposes. ${ }^{\text {, } x}$ Despite this rhetorical distancing of the East India Company from the project, it donated the land for the Cathedral, ${ }^{1 \mathrm{i} i}$ and also appointed two additional Chaplains for the duties of the new Church. ${ }^{\text {lxii }}$ Wilson's biography and his own writings further reveal that during a quick visit home, the Bishop even had a private audience with the Queen and Prince consort in March 1846. Having examined his plans, 'Her Majesty subsequently gave the communion plate for the cathedral, consisting of ten pieces of silver plate richly gilded, and bearing suitable inscriptions. ${ }^{\text {, } x i i i}$ 
The style of architecture and the location of the cathedral was carefully chosen to reflect the lofty purposes of its building. Since the Cathedral at once had to embody Protestant discipline and the stature of the Calcutta diocese, a grand gothic building was originally envisaged. Wilson regretted that the final appearance of the cathedral was affected by the compromises necessary to adapt to adverse climatic conditions and the limited finances. In his 1841 Report he proclaimed 'the style of architecture originally proposed has been adhered to, except where the soil and climate of Bengal have interfered. It is Gothic, or, as Mr Britton terms it, Christian, modified by the circumstances that is Indo-Gothic, or Indo-Christian, if such words may be allowed. 'xiv On the one hand, the cathedral was built in the lineage of some of the best specimens of English cathedrals: 'the Tower and spire are built in the model of the admired Norwich cathedral with improvements suggested by that of Canterbury. Most of the details of the ornaments internally and externally are from the finest specimens of the York Minister. ${ }^{\text {lxv }}$ Yet, on the other hand, adjustments due to the climate were necessary: 'the climate forbids large clustered pillars and low side-aisles and requires everything to be open, free and lofty for ventilation.' ${ }^{\text {xvi }}$

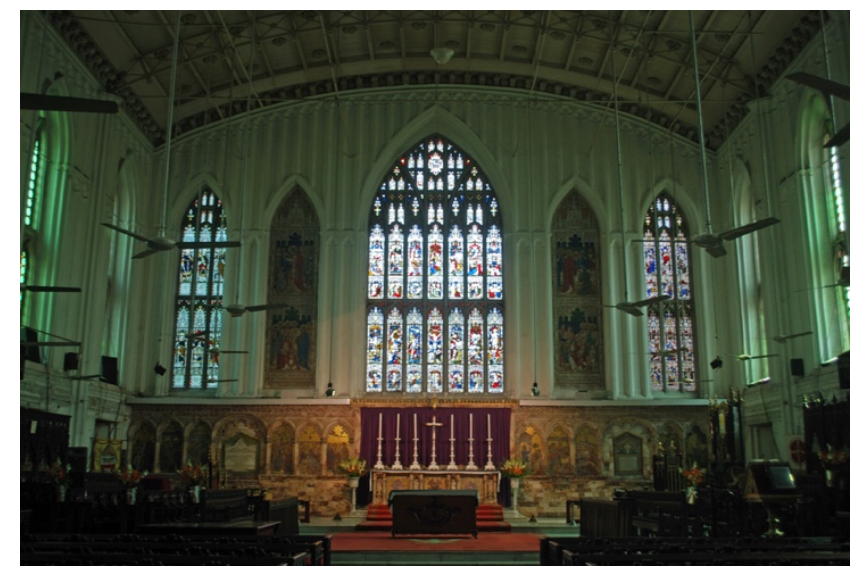

Fig 2 Contemporary Interior of the St Paul's Cathedral, Calcutta (From personal collection of Rangan Datta) Located comfortably within the 'white town', the Chowranghee area of Calcutta, on the Esplanade, was identified as the best spot for erecting the Cathedral. The area was considered 'the best the government could bestow ..., ${ }^{\text {lxvii }}$ After much consideration with the Cathedral 
Building Committee, the Bishop concluded that 'as the city of Calcutta becomes more and more occupied by offices and houses of merchandise ... it is probable that Chowranghee, taken as a centre point will become the spot around which the main body of the whole Christian community of Calcutta will be collected. ${ }^{\text {,xviii }}$ The vision of an imposing Protestant cathedral in the 'fine panorama of Calcutta' animated the Bishop and the committee reviewing the plans. ${ }^{\text {lxix }}$

Eventually, the 1850 Report announced, that the Cathedral was conceived as the crux of a whole new St Paul Cathedral Mission, which was to serve Indians, in the long run, by raising money in India so that the 'fluctuating and uncertain sources of income from England' could be avoided. ${ }^{\text {lxx }}$ The Cathedral Mission was to be permanently supported by an Endowment Fund created out of the money raised for the cathedral, under the sole direction of the Bishop and Archdeacon of Calcutta. As a beginning, few schools, an English Church Missionary Society (CMS) school at Allipore and a Bengali Boys school at Kidderpore among them, were established to form 'the nucleus of the infant Mission'. By 1851, Bishop Wilson's journal-entry triumphantly recorded the 'first fruit of the Cathedral Mission.' A seventeenyear old Brahmin boy from one of the schools, who was convinced of the truth of Christianity for some time, was baptized at the Cathedral. He was named 'Paul'. lxxi

\section{III}

Yet, the invocation of St Paul was not only limited to the imperial expansion of Christianity. By the end of the nineteenth century, Pauline ideas held direct appeal for leading Indian minds. Along with certain forms of Christianity, nineteenth-century Indian religions too were shaped fundamentally by the experiences of imperialism. ${ }^{\text {lxxii }}$ There is a longstanding historiographical exploration of imperial Christianity’s impact in shaping Indian religious 
thought, especially in forging the contours of modern Hinduism. ${ }^{\text {lxxiii }}$ Paul was appropriated centrally into the colonialism-inspired Hindu reform movements. Paul's letters and thoughts resonated for at least two significant Bengali intellectuals who were also among the key reformers of Hinduism. They were Keshab Chandra Sen (1838-1884), the Brahmo leader, known for his efforts to incorporate Christian theology within the framework of Hinduism to modernise it, and Swami Vivekananda (1863-1902), the Hindu monk, best known for being the flag-bearer of Vedanta to the western world through his rousing speech at the Parliament of the World's Religions at Chicago in 1893. At critical moments of their writing and speeches, the idea of an 'apostolic ministry' features centrally to convey messages of political theology. In Sen's writings, Paul featured as an inspiration behind the foundation of a New Dispensation of the reformist Brahmo order in 1881. For Swami Vivekananda, the life of Paul was instructive in conceiving the idea of a revivalistic Hindu organisation: the Ramakrishna Mission.

Keshab Chandra Sen used Pauline doctrines for distinct theological purpose in addressing his own personal crisis arising from the orthodoxy inherent in traditional Hinduism. Sen had initiated a schism with the reformist Brahmo Samaj, (originally founded in 1828) to found the Bharatbarshiya Brahmo Samaj (Brahmo Samaj of India) in 1866. The central issue of schism was his deep interest in bringing the Christian doctrine to the fore in revitalising Hindu religion. Sen's Christological inclinations were well pronounced as he had authored two wellknown essays titled 'Jesus Christ: Europe and Asia' (1866) and 'India Asks: Who is Jesus Christ' (1879) arguing that Christ needed to be comprehended beyond the institutionalised, muscular Christianity of the day. Following the Cooch Behar marriage controversy in $1878,{ }^{\text {lxxiv }}$ that lost a significant bulk of his most educated and westernised followers from the Brahmo congregation, Keshab was forced to reconceptualise his visions for the order once more. In 1881, towards the end of his life, he undertook yet another theological step in trying 
to formulate a new syncretic religious principle - the New Dispensation (Naba Bidhan). It has been described as 'a bold restatement of universalist principles' aimed not only to reconcile and transcend Hinduism and Christianity, but to bring all world religions into harmony, and to produce humans who were truly 'men of the world. ${ }^{\text {, } x x v}$ The analysis proceeded by considering in turn the three main purposes of the New Dispensation as described by its adherents, that it was intended be a 'universal religion', a 'national religion' and an 'apostolical religion'. ${ }^{x x v i}$

In a famous 1881 essay titled 'We Apostles of the New Dispensation', announcing the arrival of the new creed, Sen explicated it as a culmination and fusion of doctrines of Jewish, Christian, and Vaisnava religion, to turn the tide against the current state of religious sectarianism. He wrote, 'the Lord Jesus is my will, Socrates my head, Chaitanya my heart, the Hindu rishi my soul ... ${ }^{\text {lxxvii }}$ He claimed that that the principal features of the creed included the belief that immediacy with God required no prophetic mediation, ${ }^{1 \times x v i i i}$ as well as the goal of promoting the inclusivity towards all religions. ${ }^{\text {lxxix }}$ It was argued that the idea of syncretism delineated the New Dispensation from all other religion. Its essence was the synthesis of scriptures and prophets of not one land or nation, but those that belonged to 'many nations and lands, and principally in the land of the Aryans and Israelites. ${ }^{\text {, } x x x}$ Despite claiming allegiance to all religion, the essay is replete with references only to Christianity and the New Dispensation's direct inheritance from it. Positing the New Testament as a fulfilment of the Old Testament, he charted out a 'logical and theological' development from Moses to Jesus and then Paul. ${ }^{\text {lxxi }}$ In the same vein, Keshab Chandra Sen claimed his own New Dispensation to be 'Christ's prophecy fulfilled'. He further claimed that the followers of the New Dispensation were not just direct followers of Paul, but also the new age apostles. Proudly he proclaimed, 'if you cannot separate Paul from Christ, surely you cannot separate Paul from us. Are we not servants of Paul and Apostles of Jesus? Yes. ${ }^{\text {, lxxxii }}$ Negating the 
notion of any simplistic 'chronological succession' or mere 'theological connection', he developed the idea of 'fulfilment' as a logical succession and 'unbroken continuity' between the New Testament and New Dispensation that he explicated as 'the fulfilment of an ancient prophecy, the realisation of Christian and Pauline anticipation. ${ }^{\text {, lxxxiii }}$

Framing the new religion largely on a Pauline apostolic vision, Sen even initiated rituals like the Apostolic Durbar, that is, the 'court of apostles' and insisted on naming his chosen followers as 'apostles'. According to him, 'they were not ordained by men, but called by heaven and were above the ordinary standards of missionary life'. ${ }^{\text {lxxxiv }}$ He argued that his followers were 'the modern Pauls' who were following the footsteps of the original apostle to carry out similar crusade against caste and discrimination in India ${ }^{, \operatorname{lxxxv}}$ Sen concluded that these 'modern Pauls ' were working just like St Paul did in the ancient world towards a syncretic religious future that would merge the ideals of western and Eastern religion- for an 'undivided spirit-world, in which there is neither caste nor sect nor nationality., $1 x x x v i$

For Swami Vivekananda (1863-1902), the chief disciple of the nineteenth-century mystic saint Ramakrishna Paramhansa (1836-1886), the apostolic trajectory was a pertinent roadmap for disseminating Ramakrishna's teachings in an organised way. Recent studies on Vivekananda agree that he proposed a radical shift, indeed a 'rupture', from the mystic, inclusive, syncretism of Ramakrishna's religious ideals to propose a more hardened definition of Vedantic Hinduism and its distinctive appeal. ${ }^{\text {lxxxvii }}$ Scholars have analysed that Vivekananda's emphasis on the Vedas and the Vedanta as the core of Hinduism resulted from a growing compulsion of articulating Hindu religious nationalism. ${ }^{\text {lxxviii }}$ Even as Paul Hacker's criticism of Vivekananda's formulation of 'practical Vedanta' continue to be debated $^{\text {lxxxix }}$ scholars generally agree that in various moments in his speeches, especially those meant for his Indian audience, Vivekananda did support a notion of a muscular Hindu nationalism. Indeed, sometimes characterised as a sense of reverse spiritual imperialism, 
scholars have sometimes noted an almost evangelist fervour in the way he upheld Hindu superiority and its political significance. ${ }^{\mathrm{xc}}$

Therefore, it is significant that in explaining his own relationship with Ramakrishna, as well as in initially conceiving the Ramakrishna Mission in 1897, initially as a Math (monastic order), Vivekananda invoked St Paul's life and his work. As Swami Gambhirananda, the $11^{\text {th }}$ President of the Mission recollects in the commemorative Diamond Jubilee version of The History of Ramakrishna Math and Mission, 'the apostolic world in which the grand message of redemption was carried to the ends of the earth by St Paul and others' had a central presence in Vivekananda's decisive speech germane to the birth of the mission. Following Ramakrishna's death in 1886 , when the disciples were searching for the ideal way of carrying his spiritual legacy forward, many of them had congregated at a rather dilapidated house in Baranagore, in the northern outskirts of Calcutta, where they spent many months in meditation and spiritual asceticism. On a trip to the village of Antpur in the year 1887 on a cold December night on the Christmas Eve, when the collective spiritual devotion had heightened around an open-fire of huge logs, Vivekananda, along with eight other disciples adopted, for the first time, the idea of forming a Mission in Ramakrishna's name, pledging to a life of renunciation. After narrating the life of Jesus in his speech, Vivekananda inspired them to be 'apostles themselves to carry abroad the new message for the uplift and salvation of mankind', just like St Paul. ${ }^{\text {xci }}$ Although scholars have hinted that Vivekananda was simply attracted to the form of Christian organisation ${ }^{\text {xcii }}$, the articulation of Pauline thoughts at the critical moment of its inception indicates an interplay of form and content, a synthesis of the missionary form and aspects of Pauline-evangelical ethos with the message of Vedantism. The organisation's melding of social, religious as well as national imperatives provides yet another instance of the nineteenth-century reinterpretations of the Pauline doctrine. 
Swami Vivekananda's Irish disciple Sister Nivedita's celebrated memoir about Vivekananda titled The Master As I Saw Him notes the critical importance of Pauline doctrines for the Swami. His own writings as well as Nivedita's memoirs hold that from his readings of the critical Biblical scholarship of Ernst Renan and D.F. Strauss, Vivekananda had, in fact, began nurturing doubts about the historicity of the figure of Christ. He concluded that historically speaking 'it was St Paul alone of whom we could be sure' ${ }^{\text {xciii }}$ He is quoted to have even held that the 'old Rabbi Hillel is responsible for the teachings of Jesus, and an obscure Jewish sect of Nazarenes- a sect of great antiquity-suddenly galvanised by St Paul, furnished the mythic personality (of Jesus) as a centre of worship. ${ }^{\text {xciv }}$ Furthermore, Nivedita suggested that for Vivekananda Christ was always more of an ideal rather than a real historical character while he held Paul to be the real creator of Christianity as a faith. ${ }^{\mathrm{xcv}}$ Hence theologically as well as historically, Paul played a more decisive role than Christ in shaping the Swami's thoughts on organising Vedantic Hinduism in the modern era.

St Paul continued being invoked in Bengal as an inspiration behind the expansion of religious realm till at least 1920s. In a text written in 1926 Bengali Muslim theologian Nazir Ahmad Choudhury, for instance, drew detailed analogy between St Paul and the Caliph Hazrat Umar Farooq in expanding and consolidating Christian and Islamic realms respectively. ${ }^{\mathrm{xcvi}}$ In the wake of the heightened emotional issue of Islamic belongingness generated over the Khilafat movement of 1919-1924, Choudhury's Farooq-Charit (Life of Farooq), published in 1926 was the Bengali life of the Caliph Hazrat Umar Farooq, and was intended to recall the moral and just power of an Islamic state for twentieth century Bengali Muslims. ${ }^{\text {xcvii }}$ 
This appropriation of Paul in thinking about Hinduism's future needs to be studied in context. Even before Paul's ideas resonated with religious reformers from India in later half of the nineteenth century, there is a longer tradition of missionary efforts in rendering Paul Indian. Given Paul's extraordinary status in Protestant missionary imagination since the early nineteenth century, a range of Indian mission publications, in English as well as in vernacular languages, reveal an effort in making him a pertinent icon for Indians. In Protestant missionary writings in the nineteenth and early twentieth centuries, Paul's relevance for burning colonial issues such as the caste-system, establishment of indigenous churches and Indian nationalism were especially drawn out. Missionary literature emphasised that Pauline ideas on liberty could have important ramifications for nationalist thought.

A range of missionary texts discussed the best way to communicate the life and teachings of Paul to Indian minds. Along with the content, considerable thought was expounded on the form of these publications. The missionary and Orientalist scholar John Muir, for instance, in his 1838 essay, 'St Paul a Model for Missionary', insisted on writing in the Sanskrit metrical verse, in which 'the religion and literature of the Hindus are'. ${ }^{\text {xcviii }}$ By 1858 he had already published his remarkable Sanskrit verse life of Paul, Shri Paul Charitram followed with a promise of eventual Hindi and Bengali translations. ${ }^{\text {xcix }}$ In the lengthy preface he explained his plan for writing the life in Sanskrit verse form to make it appealing to the influential, educated class of Indians. ${ }^{\mathrm{c}}$ Written in the $1850 \mathrm{~s}$ and republished as part of his multi-volume Oriental and Linguistic Essays (1901), the missionary Robert Needham Cust's 'The Great Missionary', on the other hand, focussed closely on content as he attempted to compare Paul and his reputation as a spiritual conqueror with great Indian religious icons of the past including Rama, the mythical God-king of the Sanskrit epic Ramayana, Buddha and Nanak. ${ }^{\mathrm{ci}}$

A striking invocation of Paul related to the issue of the founding of indigenous churches for the Indian converts. Indeed, Protestant missionary Roland Allen's 1912 Missionary 
Methods: St Paul's and Ours provide a sharp contrast to Daniel Wilson's 1840's vision of building a western-styled cathedral in British India. Contrasting Allen's views with that of Daniel Wilson help us understand the variety of ends to which Pauline ideas were interpreted even within the Protestant circles. Allen's views chimed closely with that of other powerful proponents of self-governed, self-propagating indigenous church like that of the CMS missionary Henry Venn. Reflecting on the extraordinary journeys of St Paul that resulted in the founding of enduring and independent Churches in the ancient provinces of Galatia, Macedonia, Achaia and Asia, Allen critiqued the idea of establishing big mission churches 'fitted with all the ornaments of a western church' that were funded wholly by a mother church in England. ${ }^{\text {cii }}$ Allen's reading of Pauline doctrines thus prescribed more indigenised, self-financed churches that would involve the native converts in church administration.

Equally, there is a strand of Protestant missionary travel writing that picks up on Pauline allusions to journeying to 'regions beyond' as a means of authenticating the missionary endeavor to donors and intercessors back home. ${ }^{\text {ciii }}$ Recent scholarship on Victorian travel literature show that Paul's Mediterranean rambles on how to tailor the Gospel to different races was read in the light of the emerging imperial ethnological studies, and was acknowledged to be an instruction manual for global missionary expansion. ${ }^{\text {civ }}$

With regards to issues of caste and Indian nationalism, the Indian Church Commentary series (1906-1929) stands out in tailoring the Pauline epistles to discuss specific Indian needs. The Indian Church Commentary was a collaborative publication effort of the Anglican Church in India that brought bishops across South and South-east Asia to come together to produce a series of commentaries on the New Testament. ${ }^{\text {cv }}$ First produced under the supervisions of the Bishops of Rangoon and Lahore, they changed hands until they were completed under the general editorship of the Bishops of Calcutta and Lucknow in the 1920s. Of the nine titles produced in the series, six were commentaries on Pauline epistles and his life. Along with the 
Gospel of Mathew, Epistles of St John and the Book of Revelation, the Pauline letters included Paul's Epistles to Philippians (1906), to Hebrews (1929) ${ }^{\mathrm{cvi}}$, to Corinthians First and Second (1916 and 1923), to Colossians (1921) and the Acts of the Apostles (1919), the latter dwelling substantially on Paul's life. Published jointly by the Society for the Propagation of Christian Knowledge, based in Madras and London, and some additionally being published by the Macmillan Company in New York, these texts reveal a missionary print network spread across the metropole and the colonies.

Yet, the series exhibited other kinds of networks, connections and synthesis. Its most striking feature was an attempt to synthesise English critical Biblical scholarship with distinct missiological purposes, blending biblical criticism and evangelical faith. Although English scholar commentators like Joseph Lightfoot, Brooke Westcott and F.J.A Hort were invoked, their historical-critical methods had no impact on the proclaiming the supremacy of the Bible and its universal spiritual appeal for colonial societies. The section 'Lessons for India' at the end of each chapter of each of the Epistles, testified to this balance between critical Biblical scholarship, on the one hand and the reinterpretation of the Bible as a universal guide for colonial issues, on the other. Predictably, the entire series was meant to be translated into the Indian languages and by the time First Corinthians was published in 1923, some translations had already appeared in Tamil, Telegu, Marathi, Hindi and Urdu. ${ }^{\text {cvii }}$

From the series, Rev W.H.G.Holmes' Epistle to the Hebrews (1919) as well as Rev T Walker's Epistle to the Philippians (1909) engaged specifically with various facets of the caste system. A missionary among the 'low caste' Nadar community in south India, Walker pointed out that despite his high birth status in Hebrew society Paul gave up on his privileges. Walker was confident that Paul would have been a critic of the divisive caste system. ${ }^{\text {ciii }}$ Holmes' discussion of the Epistle to Hebrews, on the other hand, focussed on the dilemmas faced by Indian converts who had given up their caste status, and indeed their religion. In his 
preface to this Epistle, Bishop Westcott for instance dwelt upon the analogies between the first-century AD Hebrew Christians and the contemporary Indian Christians. He acknowledged that their allegiance to Christ's eternal kingdom 'is mistakenly regarded by many non-Christians as so denationalising that they are sometimes reckoned as strangers in their own country. ${ }^{\text {cix }}$ To help guard Indian converts against such pressures of apostasy, which was faced by Hebrew Christians in the ancient world, he recommended reading the epistle saying, 'to all who are thus tried, the Epistle to the Hebrews more than any other book in the New Testament brings warning, consolation and encouragement, it stimulates true patriotism, it checks false expectations and it recalls old enthusiasm. ${ }^{\text {cx }}$

The theme of Indian nationalism and freedom was taken up more directly by the Reverend Arthur Crosthwaite in The Second Epistle to Corinthians (1919). He used the Pauline epistles to reconcile the issue of Christian conversion with nationalist impulses of Indians. The notes to Chapter III identified 'longing for liberty' as the fundamental desire of the Indian heart. ${ }^{\text {cxi }}$ Croswaithe noted that in contemporary India the notion of liberty encompassed 'the natural development of both individual and national life. ${ }^{\text {cxii }}$ The author identified A.K. Coomaraswamy, the eminent philosopher of Indian art and Rabindranath Tagore, the foremost litterateur-philosopher as the two most prominent Indian thinkers on freedom who sought a reconciliation between individual salvation and political salvation that would help free the nation's spirit. Rev Crosthwaite drew extensively upon Paul to show that almost the entire corpus of Indian thought on liberty was already addressed in the apostolic Epistles. ${ }^{\text {cxiii }}$ He insisted that the notion of the joint salvation of the individual and the national community were most comprehensively maintained in Pauline thoughts that would empower Indians to envisage political freedom. 
St Paul did come to be associated with germane ideas of national identity and freedom for some Indians, especially the converts. Focussing on Bengali Christian sources, this section offers a glimpse of ways in which the apostolic period and Saint Paul were projected as exemplary for nineteenth-century Indians. It is important to note that these Bengali texts represented a critical distancing from evangelical attempts to uphold St Paul as an inspiration for anti-imperialism. Imbued with distinct anti-imperial sentiments, the vernacular recounting of Paul's lives also shaped processes of indigenising Christianity through constructions of India's own apostolic tradition. Simultaneously, some of them reflected on the dilemmas of being an anti-imperial Christian in British India.

Popular late nineteenth-century tracts written by Bengalis on the ancient apostolic churches reveal an abiding interest in the history of early Christianity. Written mostly by Protestant converts, a few also came from the Catholic stable. Authors of these texts claimed that they were driven by a strong sense of moral urgency - Rev R Biswas, thus, mentioned that his book Early Church History Upto the Fifth Century was produced despite financial duress. ${ }^{\text {cxiv }}$ Some emphasised on learning individual life-stories (Jibon Charit) to know "what kind of pious souls they had ... and how each of our lives should be like' ${ }^{\text {cxv }}$ For others, writing about early Christianity was a means to explore the functioning of the early Church, or a way of learning the true essence of Christian discipline. ${ }^{\text {cxvi }}$ Written as part of the 'Studies in Apostolic Fathers' series, Nityagopal Mukhopadhyay's Prachin Dharma-Shikkha (Ancient Religious Teachings) highlighted the importance of learning about the early days of Christianity in the first Century AD to understand its uncontaminated continuity for the past nineteen centuries. ${ }^{\text {cxvii }}$

St Thomas featured in many of these texts as the founder of the ancient apostolic church in India. ${ }^{\text {cxviii }}$ Indeed, discussions on India's own apostolic tradition featured quite often that highlighted Christianity's historical Indian roots. An awareness of nineteenth-century 
Biblical research becomes apparent because relevant research articles from the academic journal Asiatic Researches were cited that discussed the issue of historical evidence on Thomas' travel to India. ${ }^{\text {cxix }}$ Citing Graeco- Roman historians like Eusebius and Origen, other connections between ancient Christianity and India were also drawn to dismiss the idea of Christianity's foreignness in India. ${ }^{\text {cxx }}$ Overall, they argued that Christian Churches already had deep historical roots in India and that they were steeped in their own apostolic traditions. $^{\text {cxxi }}$

These Bengali early Church histories had a sizeable section devoted to the discussion of Paul's life. Together, they upheld a unique status for Paul among all the other apostles. The chapter on Paul in the 1872 book Sadhu Charitra (Lives of Saints), for instance, recommended readers to read Chrysostom's account of Paul to help them become the true disciples of Christ. ${ }^{\text {cxxii }}$ It was underlined that of all the apostles of Christ, Paul was the one who travelled and preached Christianity most extensively, ${ }^{\text {cxxii }}$ the one who brought about the most widespread conversions and also the one to have suffered the most. ${ }^{\text {cxxiv }}$ It was acknowledged that 'all the apostles suffered pain for their faith ... were hurt by various means for propagating Christianity. Yet, no one suffered as much as St Paul did. ${ }^{\operatorname{cxxv}}$ The Bengali biographies of Paul are replete with minute details of his missionary journeys and of the extraordinary miracles that he performed - whether it was giving life to the dead or healing the diseased. ${ }^{\text {cxxvi }}$ The episodes of miracles were portrayed as bringing about a radical change of heart in people, including the Roman guards at Philippa who wished to be baptised after witnessing Paul's miracles within the prison. ${ }^{\text {cxxvii }}$

Unlike the missionary narratives, however, the Bengali renderings emphasised Paul as an anti-imperial character. He was described to be fighting the imperial forces, as much as fighting Judaism, to spread early Christianity. The Bengali writings about Paul are often stories of Paul's own victimhood, dotted with horrific accounts of hostility faced by the 
apostles from the Jews as well as persecution and numerous incarcerations by Romans. They detail St Paul's multiple imprisonments in Caesarea, especially the two years of house imprisonment in Rome under the Roman Governor Felix and Emperor Nero, during which he continued to preach even while he was in chains. ${ }^{\text {cxxviii }}$ One of the texts claim that St Paul's 'Letter to Ephesians', in which he argued that it was far better to be a prisoner for Christ than even possessing the royal crown, was written when he was himself suffering in the hands of emperor Nero. ${ }^{\text {cxxix }}$ Commenting on Paul's Letter to Philemon for freeing the slave Onesimus, another claimed that the saint was critical of Roman Empire for promoting slavery. ${ }^{\text {cxxx }}$ While History of the Apostles recounted and compared the tragic last days of Paul and Peter ${ }^{\mathrm{cxxxi}}$, Sadhu Charitra, reminded the reader that it appears from the words of Saint Clement that Emperor Nero was even present where Paul was martyred. ${ }^{\text {cxxxii }}$ Despite Biblical ambiguity about Paul's death, the narrative of martyrdom by being beheaded in the hands of the Roman guards was widely accepted as standard and many books were accompanied with illustrations of compelling scenes of Paul's martyrdom. ${ }^{\text {cxxiii }}$ Thus, conversion to Christianity following Paul's footsteps appeared perfectly compatible with emerging anti-imperial, national sensibilities in nineteenth-century India.

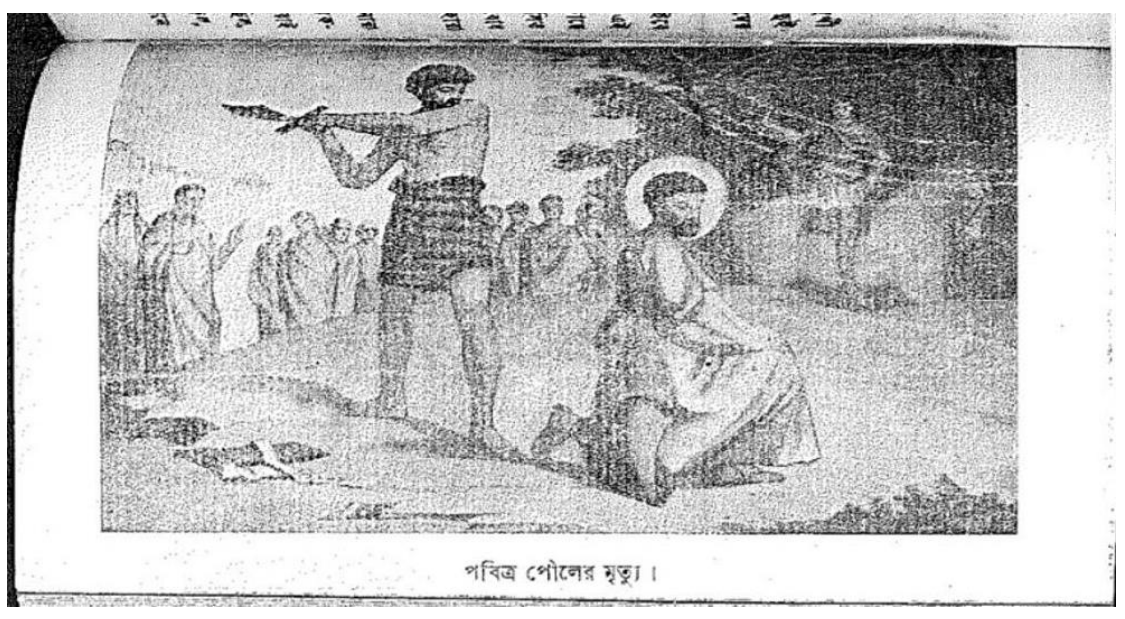

Fig 3 Martyrdom of St Paul, Anonymous, Sadhu Charitra: Lives of Apostles and Saints of the Early Church, (Calcutta, 1872), p.77 
The tensions of being an anti-imperial Christian in India become further evident from the writings of Bengali converts like Rev Lal Behari Day (1824-1892) who was a missionary and minister of the Free Church of Scotland and for whom St Paul had special relevance. He was a convinced convert to Protestant Christianity in his youth and upheld the liberal, progressive values inculcated by the British Empire. ${ }^{\text {cxxiv }}$ Rev Day's later works, however, reveal reflections on his identity as an Indian Christian in colonial times, albeit before the stronger nationalist stirrings of the 1880 s and 1890 s were evident. In a remarkable essay suggestively titled 'Searchings of the Heart', written in the wake of the revolt of 1857, Lal Behari Day grappled for the first time with his problem with the missionaries in India, who he felt were fuelled by an imperial arrogance. ${ }^{\text {cxxxv }}$ Outlining the faults in contemporary evangelising methods in India that generated racial hierarchy ${ }^{\text {cxxxvi }}$, Rev Day contended that what made Paul the biggest missionary of all times was his respect and compassion for the civilisation and achievements of the people he sought to convert. ${ }^{\text {cxxxvii }}$ By invoking Paul, Rev Day, unlike the English missionaries discussed earlier, was insisting on a crucial disjunction between Christianity and imperialism: he urged his fellow converts to be Christians while resisting racial hierarchies and imperialist arrogance.

This is not to suggest any definitive fault line between imperial Christianity and vernacular Christianity, or that the latter was characterised only by anti-imperialist sentiments. A number of scholars have highlighted the mutual cooperation and reciprocity in the way Western missions in India and the Indian converts functioned over the years. ${ }^{\text {cxxxviii }}$ Not only the local converts, but scholarship on representative European missionary figures such as Henry Venn, C.F.Andrews or James Long too suggest a certain porosity of the European- Indian divide. ${ }^{\text {cxxxix }}$ These works illustrate that the tropes of 'friendship', 'cooperation' and 'empathy' for the converted were central to operations of these missionaries in India. Evidently, many of them were firm believers in the immediate 
devolution of church power to the natives. Yet, it needs to be equally noted that whether a native Indian church could be ever raised independently of British supervision, was a contentious issue in mission administration. ${ }^{\text {cxl }}$ This is evidenced by the frictions of opinion that happened between even the most committed Indian converts like Krishna Mohan Banerjea or Lal Behari Day with the mission functions. ${ }^{\text {cxli }}$ Hence, questions of political rights, racial discrimination and related issues of anti-imperialism cannot be completely divorced from histories of vernacular Christianity. Lal Behari Day’s criticism of the Bengal mission in the late 1850s, based on his reading of St Paul, thus, provides a unique glimpse of South Asian Christianity, where Christian icons provided by the missions were appropriated to raise voices of protest against a perceived collusion between British empire and evangelical missions.

\section{VI}

St Paul remains one of the most significantly controversial characters in history - his life and letters have been open to multiple interpretations through time. Simultaneously celebrated for his Christological statements that had significant ramifications for the development of New Testament spirituality and hailed as the second founder of Christianity, he is also often accused of being the father of Christian anti-semitism. With regards to relationship between religion and politics, the apostle, more than any other Biblical figure, provides a unique site to study nineteenth-century Indian political theology. The nineteenth-century evangelical literature on Paul suggested connections between Roman, British and Christian spiritual empires. Therefore, this essay highlights Paul as a crucial reference point around which the interactions between British imperialism and Christianity in India need to be studied. Paul's nineteenth-century life in India provides a prism to explore the ways in which ideals of religious expansion and political consolidation came together. Life of individual Anglican missionaries as Daniel Wilson in British India unravel such convergence of political and 
religious motivations. The article further focuses on some of the material manifestations of imperial ideology through missionary activities around Pauline thoughts. But in exploring the relationship between protestant missions and cultural imperialism, this paper has also paid equal attention to the ways in which colonised Indians appropriated Paul as an icon of religious reform and anti-imperial sensibilities. In so doing, the essay aligns itself with the postcolonialism-inspired 'new mission history" ${ }^{\text {cxlii }}$ that seeks to understand local voice and upholds the importance of local agency in locating the place of Christianity in distinct societies.

With its focus on St Paul this article has explored many strands of Christianity's cultural translation and vernacularisation in South Asia. It illustrates how Christianity was at once resisted, appropriated and ascribed with new meaning. Paul stood for a symbol against racial hierarchies among converts, he helped spin a genealogy of Indian Christianity that went far beyond the limits of British rule in the subcontinent to India's own apostle Thomas and even provided a theological repository for the Hindu reformers to work with. Interpreting Christianity through the preaching, morality or discipleship of Paul was as much a matter of personal faith as also of articulating collective identities as Indians. Such articulations in the ultimate analysis demonstrates the reconstitution of St Paul as a Christian symbol that was historically contingent, and yet distinctly Indian.

Centre for Research in Arts Social Science Humanities, University of Cambridge, sd591@cam.ac.uk

* I am grateful to the editors and the two anonymous referees at The Historical Journal for their incisive comments. I would like to thank Simon Goldhill, Michael Ledger-Lomas, Gareth Atkins and other members of the ERC project 'Bible and Antiquity in Nineteenth Century Culture' at the University of Cambridge for their critical engagement with drafts of this paper. An earlier version was presented at the World Christianity Workshop at Cambridge - I thank the organisers Joel Cabrita, David Maxwell and other participants in the workshop, as well as Rohan Deb Roy, for their most helpful feedback.

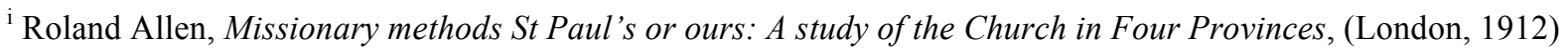
pp. 4-5 
ii Ibid., pp. 38-39

iii Keshab Chandra Sen, "We Apostles of the New Dispensation", in T.E Slater ed., Keshub Chunder Sen and the Brahmo Samaj: Being a brief review of Indian theism together with selections from Mr Sen's work, (Madras, 1884) pp. 464-465

iv See M.M. Thomas, The acknowledged Christ of the Indian renaissance, (London, 1969), Jan Peter Schoutan, Jesus as guru: The image of Christ among Hindus and Christians in India, (Amsterdam, New York, 2008)

v Jean and John Comaroff, Of revelation and revolution: Christianity, colonialism and consciousness in South Africa, (Chicago, 1991)

${ }^{\mathrm{vi}}$ Hilary Carey, God's empire: religion and colonialism in the British world c 1801-1908, (Cambridge, 2011), Alex Bremner, Imperial gothic: religious architecture and high Anglican culture in British Empire c1840-1870 (Yale, 2013)

vii Jeffery Cox, Imperial faultlines: Christianity and colonial power in India, (Stanford, California, 2002), pp. 23-51

viii R.S. Sugirtharajah, Bible and empire: postcolonial explorations, (Cambridge, 2005)

${ }^{\mathrm{ix}}$ See for instance, Norman Vance, 'Imperial Rome and Britain's Language of Empire' in History of European Ideas, 26, (2000), pp. 211-224

${ }^{\mathrm{x}}$ Some initial conversation has begun in this direction. For a study of the place of St Paul in a pan-Asian context see R.S. Sugirtharajah, The Bible and Asia: from pre-Christian era to the postcolonial Age (Cambridge MA, 2013) pp. 152-189. For a recent foray into the Victorian scholarly engagements with Paul with relation to the ideals of evangelicalism see Robert Paul Seesengood, 'Wrestling with the Macedonian call': Paul, Pauline scholarship and nineteenth century colonial missions', in Christopher Stanley ed., The colonised apostle: Paul through the postcolonial eyes, (Minneapolis, 2011), pp. 189-203.

${ }^{x i}$ Hilary Carey, God's empire, pp. 5-10

${ }^{x i i}$ Andrew Porter, Religion vs empire: British Protestant missionaries and overseas expansion, 1700-1914, (Manchester, 2004) For a dense exploration of the relationship between Protestant missions, spiritual and political expansion see Sujit Sivasundaram, Nature and the godly empire: science and evangelical mission in the Pacific, 1795-1850, (Cambridge, 2005) For an exploration between Anglicanism and empire see Rowan Strong, Anglicanism and the British empire, c.1700-1850, (Oxford, 2007), pp. 118-197

xiii John Wolffe, 'Anti-Catholicism and British Empire,1815-1914' in Hilary Carey ed., Empires of religion, (Basingstoke, 2008), pp. 43-63

xiv There is a body of emerging literature on the theme. For a rich discussion see Isabel Hofmeyr, Portable bunyan: transnational history of the Pilgrim's Progress, (Princeton, 2004). See Ronit Ricci, Islam translated: literature, conversion and the Arabic cosmopolis of south and south east Asia (Chicago, 2011)

${ }^{\mathrm{xv}}$ Saurabh Dube, 'Conversion to translation: colonial registers of a vernacular Christianity', South Atlantic Quarterly, 101, (2002), pp. 807-837. For a pioneering work on the particularities of South Indian Christianity through studies of specific shrines, divinities and cults and their relation to polity see Susan Bayly, Saints, goddesses and kings: Muslims and Christians in South Indian society, 1700-1900, New York, 1989).

${ }^{x v i}$ For a summary discussion of these concepts drawn from postcolonial thinkers like Bhabha, Prakash and Pratt with relation to colonial Christianity see Jeffrey Cox, Imperial faultline, pp. 14-17. For a recent exploration of the 'dynamic and multi-faceted model' of missionary religious encounter in world history see David Maxwell, 'The missionary movement in African and world history: mission sources and religious encounter', The Historical Journal, 58 (2015), pp. 901-930

${ }^{x v i i}$ See for instance Christopher Harding, Religious transformation in South Asia: meanings of conversion in colonial Punjab, (Oxford 2008), Rowena Robinson and Joseph Marianus 
Kujur eds., Margins of faith: Dalit and tribal Christianity in India, (Los Angeles, London 2010). Though not directly about conversion, Saurabh Dube's Untouchable pasts raises important question about history, subaltern pasts and questions of conversion as resistance. See Saurabh Dube, Untouchable pasts: religion, identity and power among a central Indian community (Albany, 1998)

xviii Gauri Viswanathan, Outside the fold: conversion, modernity, belief, (Princeton, 1997)

${ }^{x i x}$ Bernard Lucas, Empire of Christ: being a study of the missionary enterprise in the light of modern religious thought, (London, 1908), pp. 149-151

${ }^{x x}$ Ibid., p. 149

${ }^{x x i}$ According to the Bible's New Testament, the apostles were the primary disciples of Jesus Christ. Christian tradition refers to the apostles as being twelve in number and the period of Early Christianity during the lifetimes of Jesus and the apostles is called the Apostolic Age. Although not one of the Twelve apostles commissioned during the life of Jesus, Paul is still considered a special apostle having authored almost half the books of New Testament and also having claimed a special commission from the resurrected Jesus.

${ }^{x x i i}$ Lucas, Empire of Christ, p. 149

xxiii George Smith, Short history of Christian missions from Abraham and Paul to Carey, Livingstone and Duff, (Edinburgh,1884) pp. 52

${ }^{x i v}$ Joseph Lightfoot, Comparative progress of ancient and modern missions: a paper read at the annual meeting of the Society for the Propagation of Gospel in Foreign Parts, April 1873, (London, 1880)

${ }^{\mathrm{xxv}}$ Ibid., p.7

${ }^{x x v i}$ Ibid., p. 9

xxvii Josiah Bateman, Life of right rev Daniel Wilson, late Lord Bishop of Calcutta and

Metropolitan of India, (London, 1860), pp. 243-244

${ }^{x x v i i i} \mathrm{G}$ Barnett Smith, Eminent Christian workers of the nineteenth century, (London, 1893), p. 176

${ }^{\text {xxix }}$ Ibid., pp. 191-192

${ }^{\mathrm{xxx}}$ In the context of 1830 s ecclesiastical politics these were loaded terms. The Tractarians talked a lot about apostolic succession (from the early Church and especially the Fathers), and evangelical anti-Tractarians like Wilson were keen both to appropriate the same language (the Church was derived from Christ and the apostles, not rationalism or political authority or expediency), but also to redefine it: apostolic as the pure simplicity of the early Church, not the more elaborate and corrupt thing that came later. Paul was a keystone of that effort.

xxxi Josiah Bateman, Life of Daniel Wilson, pp. 223-224

${ }^{x x x i i}$ G. Barnett Smith, Eminent Christian workers, pp. 198-199, also Josiah Bateman, Life of Daniel Wilson, p. 678

xxxiii Daniel Wilson, Apostolical commission considered: with reference to the authority of the clergy of the Church of England, (Calcutta, 1835)

${ }^{x x x i v}$ See Daniel Wilson, Sermons delivered in India, (London, 1838), pp. 465-467

${ }^{\mathrm{xxx}}$ Daniel Wilson, Expository lectures on St Paul's Epistle to Colossians: being an attempt to apply the apostle's argument respecting the errors on the subject of the mediation of Christ at Colosse to the present circumstances of the Church, (New York, 1859)

xxxvi Ibid., pp. v-vi

xxxvii Ibid., p. 15

xxxviii Ibid., pp. 144-145

${ }^{x x x i x}$ Daniel Wilson, Expository lectures on St Paul's Epistle to Colossians, (London, 1845), pp. 114-115

${ }^{\mathrm{xl}}$ Ibid., p. 4

xli Ibid., pp. 7-8

xlii Ibid., pp. 7-8 
xliii Ibid., pp. 52-53

xliv Ibid. pp. 297-304

xlv Ibid., pp. 28-29

xlvi Ibid., pp. 175-180

xlvii Josiah Bateman, Life of Daniel Wilson, 1860, p. 528

xlviii Ibid., p. 529

${ }^{\text {xlix }}$ Report of the new cathedral of St Paul, Calcutta from June 1839 to October 1841, (Calcutta, 1841), p. 59

${ }^{1}$ D Catley, A short history of St Paul's cathedral, (Calcutta, 1960) pp. 12-13

li Christopher Bayly, 'Empires of religion' in The birth of the modern world: global connections and comparisons, (Oxford, 2004), pp. 359-361

${ }^{\text {lii Alex Bremner, Imperial gothic, pp. 5, } 69}$

liii Thomas Metcalf, 'Architecture and the representation of rmpire: India, 1860-1910', Representations, 6 (1984), pp. 37-65

${ }^{\text {liv }}$ For a discussion of this transition from classical to gothic style see Jan Morris, Stones of empire: buildings of the raj, (Oxford, 2005), pp. 27-29

${ }^{1 v}$ Report of the new cathedral of St Paul, Calcutta, (Calcutta, 1841), p. 68

lvi Ibid., pp. 25-26

lvii Ibid.

lviii Final report of the St Paul's cathedral Calcutta to which is prefixed the sermon delivered on the occasion of the consecration by the Bishop, (Calcutta, 1847), pp. 11-17

lix Ibid

${ }^{1 x}$ Report of the new cathedral of St Paul, Calcutta, (Calcutta, 1841), pp. 13-15, 21.

lxi Ibid., pp. 53, 62

lxii Ibid., pp. 15-16

lxiii G Barnett Smith, Eminent Christian workers, 1893, pp. 196-197

${ }^{1 x i v}$ Report of the new cathedral of St Paul, Calcutta, (Calcutta, 1841) pp. 5-6

${ }^{1 x v}$ Final report of the St Paul's Cathedral Calcutta, (Calcutta, 1847), pp. 5-6.

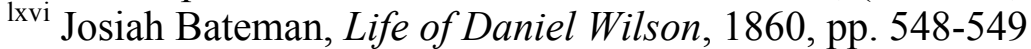

${ }^{\text {lxvii }}$ Report of the new cathedral of St Paul, Calcutta, (Calcutta, 1841), p. 44

lxviii Ibid., pp. 44-45

lxix Ibid., pp. 46

${ }^{1 x x}$ Report of St Paul cathedral funds and the commencement of the Cathedral Mission to which is prefixed a sermon delivered by the Bishop at the third anniversary of the consecration, (Calcutta, 1850), pp. 3-31

lxxi Josiah Bateman, Life of Daniel Wilson, 1860, pp. 651

lxxii Christopher Bayly, 'Empires of Religion', pp. 330-332

lxxiii See Arvind Sharma ed., Neo-Hindu views of Christianity, (Leiden, New York, 1988)

Ixxiv The Cooch Behar episode was a personal controversy that Sen got involved in 1877 when he was publicly criticized for getting his underage daughter married to the Maharajah of Cooch Behar. Since the marriage flouted the newly instituted Marriage Act of 1872, Sen was seen to be going back on his own reform agenda.

${ }^{\text {lxxv }}$ While older analysis like that of Meredith Borthwick, Keshab Chunder Sen: a search for cultural synthesis (Calcutta 1977) considers the New Dispensation as a synthesis between Christianity and Hinduism, newer analysis is increasingly holding it to be an attempt at universalism, fusion of all religion, see, John Stevens, Colonial subjectivity: Keshab Chandra Sen in London and Calcutta, Unpublished Dissertation, (University College London, 2011) ${ }^{\text {lxxvi }}$ P.C.Mozoomdar, The life and teachings of Keshub Chunder Sen, ( $3^{\text {rd }}$ edn, Calcutta, 1931) p. 350

lxxvii Keshab Chandra Sen, "We Apostles of the New Dispensation”, pp. 491 
lxxviii Ibid., pp. 452-453

lxxix Ibid., p. 456-457

Ixxx Frans Damen, Crisis and religious renewal in Brahmo Samaj (1860-1884), (New Delhi, 1983), p. 194

lxxxi Keshab Chandra Sen, "We Apostles of the New Dispensation”, pp. 461-463

lxxxii Ibid., pp. 464-465

lxxxiii Ibid.

${ }^{\text {lxxxiv }}$ Frans Damen, Crisis and religious renewal, p. 201

${ }^{1 x x x v}$ Keshab Sen, 'We Apostles of New Dispensation', p. 467

lxxxvi Ibid., p. 488

lxxxvii Jyotirmoy Sharma, Restatement of religion: Swami Vivekananda and the making of

Hindu nationalism, (New Haven and London, 2013), pp. xiii-xi

lxxxviii Ibid., pp. xvii

${ }^{\text {lxxxix }}$ For a reflection on the debates around Paul Hacker's formulation see Wilhelm Halfbass

ed., Philology and confrontation: Paul Hacker on traditional and modern Vedanta, (Albany 1995)

${ }^{x c}$ R W French, 'Swami Vivekananda's experiences and interpretations of Christianity' in Arvind Sharma ed., Neo-Hindu Views of Christianity, pp. 95-98

xci Swami Gambhirananda, History of Ramakrishna math and Ramakrishna mission, (Calcutta, 1957) pp. 38-39

${ }^{x c i i}$ Gwilym Beckerlegge, The Ramakrishna mission: making of a modern Hindu movement, (New Delhi, 2000), pp. 73-76

xciii Sister Nivedita, The master as I saw him, (Calcutta, 1910, Reprint 1972), pp. 232-33

${ }^{x c i v}$ R W French, 'Swami Vivekananda's experiences and interpretations of Christianity', pp. 100-101. Also, see Nivedita, The master as I saw him, pp. 230-233.

${ }^{x c v}$ Ibid., pp. 232-233

${ }^{x c v i}$ Nazir Ahmad Choudhury, Farooq Charit (Life of Farooq), (Calcutta, 1926), pp. 6-9 xcvii Ibid.

xcviii John Muir, 'St Paul a model for the missionaries', Calcutta Christian Observer, (1838), pp. 68-69

${ }^{x c i x}$ John Muir, Shri Paul charitram: A short life of the apostle Paul with a summary of

Christian doctrine as upholded in his epistles, (Calcutta, 1850)

${ }^{\mathrm{c}}$ Ibid., pp. i-vii

${ }^{c i}$ Robert Needham Cust, 'The great missionary' in Linguistic and oriental essays, Vol 6, (London, 1858) pp. 135-144

cii Roland Allen, Missionary methods St Paul's or ours, pp. 70, 175,182

ciii Michael Ledger-Lomas, 'In the footsteps of St Paul' in Brian Murray and Mary Henes eds., Travel writing, visual culture and form, 1760-1900, (Basingstoke, 2016), pp. 164-165 civ Ibid.

${ }^{\mathrm{cv}}$ See E F Brown, First epistle of Paul the apostle to Corinthians with introduction and notes, (London, Madras, 1923), pp. vii-viii

cvi Although Protestants at the time believed Paul to be the author of Epistle to Hebrews, current New Testament scholarship mostly considers its authorship unknown.

cvii Ibid.

cviii T. Walker, Epistle to Philippians, (London, Madras, New York, 1909), pp. 69-70. The invocation of Pauline epistles by missionaries specifically around the issue of caste has been hinted also by R.S Sugirtharajah. See Sugirtharajah, The Bible and Asia, pp. 161-163

${ }^{\text {cix }}$ W.H.G. Holmes, The epistle to Hebrews, (London, Madras, New York, 1919), pp. vii-x ${ }^{\mathrm{cx}}$ Ibid. 


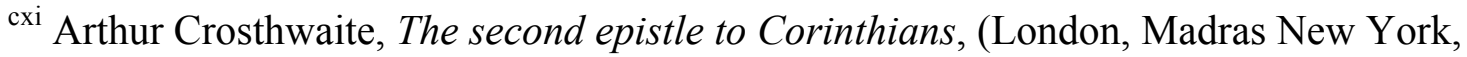
1919), pp. 63-73

cxii Ibid., pp. 66-67

cxiii Ibid., pp. 69

${ }^{\text {cxiv }}$ R Biswas, Early Church History Upto the Fifth Century, (Cossipore, 1921), p. 1

${ }^{\mathrm{cxv}}$ Anonymous, Preritodig er itihash (History of the apostles), (Dacca, 1921), Preface, page not numbered.

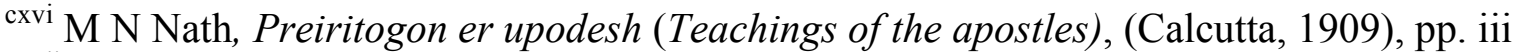

cxvii Nityagopal Mukhopadhyay, Prachin dharma shikkha (Ancient religious teachings), (Calcutta, 1895), p. 1

cxviii For a comprehensive historical account of the St Thomas Christians of South India in the precolonial and colonial period see Susan Bayly, Saints, Goddesses and Kings, pp. 218-281

${ }^{\text {cxix }}$ Nityagopal Mukhopadhyay, Prachin dharma shikkha (Ancient religious teachings), p.

181

cxx Ibid., p. 180, See the long discussion on Origen's testimony on St Thomas. Also, pp.182185

cxxi Ibid., p. 19

cxxii Anonymous, Sadhu charitra: lives of apostles and saints of the early church, (Calcutta, 1872), pp. 73

cxxiii Anonymous, History of the apostles, p. 23

${ }^{c x x i v}$ Anonymous, Sadhu Charitra: lives of apostles and saints of the early church, p. 48

${ }^{\mathrm{cxxv}}$ Anonymous, History of the apostles, p. 63

${ }^{c x x v i}$ Anonymous, Sadhu charitra: lives of apostles and saints of the early church, pp. 46-47, 54-56

cxxvii Ibid., pp. 51-52

cxxviii Ibid., pp. 63-73. Also, see, Anonymous, History of the apostles, pp. 64-65

cxxix Anonymous, Sadhu charitra: lives of apostles and saints of the early church, p. 76

${ }^{\text {cxxx }}$ Ibid, p. 7

cxxxi Anonymous, History of the apostles, pp. 68-70

cxxxii Anonyous, Sadhu charitra: lives of apostles and saints of the early church, pp. 78

cxxxiii Anonymous, History of the Apostles, pp. 68-69

${ }^{\text {cxxxiv }}$ For his belief in the ideals and values of the British empire see Lal Behari Day, 'The influence of the Bible on nations', in Essays on The Bible for educated men in India, (Madras, 1885), pp. 207-237

${ }^{\mathrm{cxxxv}}$ Lal Behari Day, Searchings of heart in connection with missions in Bengal, (Serampore, 1858)

cxxxvi Ibid., p. 11

cxxxvii Ibid., p. 11

cxxxviii See Robert Frykenberg and Alaine Low eds., Christians and missionaries in India:

Cross cultural communication since 1500, (Grand Rapids, MI, 2003) and Daniel Jeyaraj,

'Indian participation in enabling, sustaining and promoting Christian mission in India', in

Richard Fox Young ed., India and the Indianness of Christianity, (Grand Rapids, Michigan, 2009), pp. 26-40

${ }^{\text {cxxxix }}$ Leela Gandhi, Affective communities: Anti-Colonial thought, fin-de-siecle radicalism and the politics of friendship, (Durham and London, 2006), pp. 13-18 and Geoffrey Oddie, Missionaries, rebellion and proto-nationalism: James Long of Bengal, 1814-87, (Richmond, 1999). Especially see the chapter 'Indigenous Churches and the Problem of Growth, 18501861 ', pp. 68-81

${ }^{\mathrm{cxl}}$ Ankur Barua, Debating 'conversion' in Hinduism and Christianity, (New York, 2015), pp. 53-56 
${ }^{c x l i}$ For an account of the confrontation between Banerjea or Day with the Protestant missions in Calcutta in the 1840 s and 1850s on grounds of racial discrimination and hierarchy see Antony Copley, Religions in conflict: ideology, cultural contact and conversion in late colonial India, (Delhi, 1997), pp. 226-238 and Nandini Chatterjee, 'The political theology of Indian Christian citizenship: Krishna Mohan Banerjea to K.T. Paul', paper delivered at the University of Cambridge, 2012, pp. 2-11,

$<$ http://webcache.googleusercontent.com/search?q=cache:nF0W6VZ4EYgJ:www.cccw.cam.ac.uk/media/docu ments/HMC\%2520seminars\%25202012/N Chatterjee ChristianCitizenship.doc + cd $=1 \&$ hl $=$ en \&ct=clnk\&gl=u $\underline{\mathrm{k} \& \mathrm{client}=\text { safari }>}$

cxlii Heather Sharkey, Cultural conversions: unexpected consequences of Christian missionary encounters in the Middle East, Africa and South Asia, (Syracuse, 2013), pp. 4-7 